\title{
Relaxation Technique within Group Counseling to Reduce Student's Anxiety on Facing Exam
}

\author{
Arizona Arizona ${ }^{1}$, Nurlela Nurlela ${ }^{2}$, Zhila Jannati ${ }^{3}$ \\ Universitas PGRI Palembang, Indonesia ${ }^{1,2}$ \\ Universitas Islam Negeri Raden Fatah, Indonesia ${ }^{3}$ \\ @arizona.karno@gmail.com ${ }^{1}$
}

Article Information:

Received September 19, 2018

Revised October 18, 2018

Accepted January 1, 2019

Keywords: group counseling; relaxation; instrumental music; anxiety

\section{Abstract}

The purpose of this study is determine the effectiveness of group counseling model with relaxation technique assisted by instrumental music to reduce students' anxiety on facing exam. This type of research is quantitative with quasi-experimental research design, using the initial test design (pretest) and the final test after treatment (posttest). This research involved PGRI junior high school 1 Palembang students. The steps taken are: 1) preparation, 2) giving the pretest to the experimental group, 3) giving treatment 4), conducting posttest, and 5) the analysis of effectiveness of group counseling with relaxation techniques assisted by instrumental music to reduce the anxiety of students when facing exam. The analysis was carried out using the Wilcoxon test. Based on the results of the test, the level of students' anxiety faces the test has decreased after participating in group counseling activities with relaxation techniques. The Wilcoxon test results obtained Asymp.sig. (2-tailed) of 0.008 with 5\% significance $(<0.05)$. Therefore, it can be concluded that group counseling services with relaxation technique assisted by instrumental music is effective to reduce students' anxiety on facing exam.

\section{INTRODUCTION}

As a part of education, guidance and counseling is series of assistance efforts (Wibowo, 2005). The services formed as direct contact with counselee, this greatly supports the success in helping process. Guidance provided to counselee to make them achieve the general goals of education.

Anxiety will disrupt interfere sleep cycle and reduce body fitness (Reilly \& Edwards, 2007) then reduce appetite (Levinson \& Rodebaugh, 2016). Further impact that could happen is lack of learning concentration, physical pain or cause social interaction problem. Otherwise, if anxiety experienced in an appropriate level it would make someone will be more effective in life (Maba, 2017).

Anxiety symptoms both acute and chronic is a major component of almost all psychiatric disorder. Clinically, anxiety disorders are divided into several groups, namely: anxiety disorders, panic disorders, phobia and obsessive-compulsive disorder (Hawari, 2008). Someone who is categorized as having anxiety will have an impact on his daily life, the activity he does typically will not be optimum.

Anxiety is a psychological problem that is shown by an attitude of worrying about something that is poorly perceived by the individual. Anxiety is a kind of discomfort, worry, and fear of something that is not clear (Barlow, 2013). Something frightening is obvious

How to cite:

E-ISSN:

Published by:

Available online:
Arizona, A., Nurlela, N. \& Jannati, Z (2019). Relaxation Technique within Group Counseling to Reduce Student's Anxiety on Facing Exam. Islamic Guidance and Counseling Journal, 2(1). 33-39. https://doi.org/10.25217/igcj.v2i1.310

2614-1566

Institut Agama Islam Ma'arif NU (IAIMNU) Metro Lampung

https://journal.iaimnumetrolampung.ac.id/index.php/igcj 
because it is in the form of danger or something that threatens personal safety called "fear" (Gunarsa, 2008).

Anxiety is not only experienced by adults but can also be experienced by children, or adolescent who are still studying in school. For students, anxiety is an emotional disorder that can inhibit the learning process in school. In this case, students will also be disadvantaged by the learning process. Everything will not be optimum. Anxiety experienced by students in school can take the form of realistic, neurotic or moral anxiety. Because anxiety is a mental process that is not visible to the surface, to determine whether a student has anxiety or not, a careful study is needed, by trying to identify the symptoms, along with the factors underlying them. It should be noted that anxiety symptoms that can be observed on the surface are only a small part of the real problem (Barlow, 2013).

There are various disorders with symptoms of anxiety as the main symptom. Excessive worry able to grow anxiety that can affect someone lives. About one of 20 people have anxiety disorder at a time. At times of anxiety, we feel fear and tension. Also, we can also experience one or more unpleasant physical symptoms, such as a rapid heartbeat, palpitations, body aches, trembling, sweating, dry mouth, chest pain, headaches and rapid breathing (Aldrin, 2014).

In school, many factors that can trigger anxiety among student. The curriculum target is too high, the learning climate is competitive, the provision of tasks that are very solid, as well as a rigorous assessment system are factors that cause anxiety. Furthermore, the environment factors of students do not support each other and can not help solving problems encountered while attending the learning process in class and when completing homework. Therefore it is necessary to have an essential effort in dealing with issues encountered by students in facing exam both before and after.

A method to reduce anxiety when facing exam is to use group counseling service. Group counseling provides students with more opportunity to know themselves better through interactive activities. An individual can develop awareness or strength that is still hidden, interests, abilities and needs by participate group counseling (Corey, 2013). This service can be used as a vehicle for making positive contributions for students' social behavior to be directed to be more positive and can reduce student anxiety. Group counseling service is a service that is used in groups guided by an expert counselor by inviting group members to overcome the problem (Wibowo, 2005).

Group counseling is a dynamic interpersonal process that focuses (concentrates) on the awareness of thinking and behavior, involves a therapeutic function, oriented to reality; there is mutual trust in trust, there is understanding, there are acceptance and assistance (Prayitno, 2005). Group counseling activates group dynamics to discuss various things that are useful for personal development and alleviate individual problems that become participants in group activities.

Based on the phenomenon in the field, authors obtained information that the group counseling services carried out at PGRI junior high school 1 Palembang were not optimum. This is reinforced by the statement of one of the guidance and counseling teachers that the teacher has provided services on exam preparation, learning strategies, and other learning skills. However, students still have anxiety in facing exam. This is because guidance and counseling teachers as group leaders still use the conventional method, which is one approach for all problems, it causes group members become bored quickly. The implementation of group counseling is also incidental and casuistic, and a particular method for reducing anxiety in the face of student exams is not yet available. The condition of counseling and guidance services, especially group counseling services is supposed to be one of the causes of high anxiety in facing exam. Therefore, authors decided to to conduct group counseling activities with instrumental music-assisted Relaxation techniques. The relaxation is a technique to 
reduce emotional responses that are frightening, worrying or unpleasant through activities that are contrary to those responses (Willis, 2004).

School is one place for the implementation of education, in which the teaching and learning process takes place and the counseling processes, but the execution of group counseling has been carried out conventionally and has not used specific techniques to help students develop themselves and solve student problems. Judging from the perspective of guidance and counseling, it is clear that the teacher's task of guidance and counseling is needed to solve the problem of students in school. Besides that, it is also to guide, to direct, to develop and to establish the potential of participants until students are confident in their abilities.

Related with the improvement of the quality of education in the globalization era, the government always improves the work of teachers and the results of the teaching and learning process by demanding values that must be complete or exceed the minimum completeness criteria for students. Focus in the learning process is the basis for developing knowledge and the potential that exists in students, but the results we get are sometimes not the same as the goals we want to achieve in the learning process, such as anxiety because the fear of failure is one of the factors that inhibit the process.

Obstacles that arise, one of which derives from within the students, besides that, the outside factors of students can influence the learning outcomes they want to achieve, and if the obstacles that arise in the activities or learning process are not addressed or not repaired it will appear another problem in the students themselves. The relaxation technique is the technique in counseling guidance where this technique can help relax students by assisted by musical instrumental that can reduce stress levels in humans.

Group counseling with Relaxation techniques to reduce students' anxiety in facing exam emphasizes the basic assumptions of Relaxation techniques. The basic assumption underlying this technique is that responses to anxiety can be learned or conditioned, and can be prevented by providing substitutions in the form of unfriendly activities. This procedure is used primarily for anxiety and avoidance reactions. This includes analysis of the first behavior of a stimulus that causes anxiety and the construction of a hierarchy of situations that produce anxiety; then relaxation procedures are taught, and scenarios are imagined, from conditions presented in the order from the lightest to the most threatening. The stimulus that produces anxiety is repeatedly paired with relaxed exercise until the relationship between incentives and responsiveness to anxiety disappears. The research study recognizes that systematic desensitization that strengthens the assumptions above are: research found that systematic desensitization techniques and behavioral techniques can reduce exam anxiety in students (Otta \& Ogazie, 2014), biofeedback relaxation training programs in educational contexts could be a way of reducing anxiety and improving academic performance (Aritzeta et al., 2017), and another findings confirm the effectiveness and efficacy of cognitive therapy in managing anxiety and depression and improving academic performance, and when combined with relaxation technique, the combination optimizes academic performance (Akinsola \& Nwajei, 2013).

Despite of those research had found the effectiveness of relaxation on reduce anxiety and improve academic performance, but none of them had stated clearly about the effectiveness on reduce exam anxiety. Based on the problems mentioned above, the authors present an experimental study to determine the effectiveness of group counseling with relaxation group assisted by instrumental music to reduce students' anxiety in facing the school exam. The hypotheses of the research are the treatment is not effective to reduce students as null hypothesis, otherwise the treatment effective as alternative hypothesis. 


\section{METHODS}

The research method used in this study was Quasi-Experiment with the Non-equivalent Design Group Control. This form of the experiment was used to reduce the difficulty of determining the control group in the study (Sugiyono, 2013). This Non-equivalent Method of Control Group Design is a method that conducts pre-test first without randomly selecting both the control group and the experimental group so that the results of the treatment can be known more accurately.

The steps of research are; 1) preparation of the experimental group, 2) giving the pretest in the experimental group 3) giving treatment or treatment to the experimental group 4) giving posttest in the experimental group, 5) the final effectiveness of group counseling with relaxation techniques assisted by instrumental music to reduce the anxiety of students when facing exam.

The population in this study were students of PGRI junior high school 1 Palembang, with a total sample of 18 students of class VIII. Sampling in this study used purposive sampling technique. Research data obtained from students' anxiety scale in facing exam consists of 9 indicators and 23 items tested for validity with 35 students and then interview with the guidance and counseling teacher to obtain information about how the service conducted at the place. The data were analyzed using Wilcoxon test assisted by SPSS.

\section{RESULTS AND DISCUSSION}

The description of the implementation of group counseling services based on the results of interviews with the Counseling teachers. Interviews conducted by researchers focused on data relating to group counseling planning, group counseling implementation, material or problems in group counseling, group counseling time and schedule, target in group counseling activities, evaluation and follow-up, supporting and inhibiting factors, assessment of the implementation of group counseling in the form of an immediate assessment.

This research was to find out the high and low anxiety of students in facing the exam measured by the student's anxiety scale in facing the exam regarding students' anxiety in facing the exam. Categories used to determine students' anxiety in facing exams are high, medium, low, less. For the implementation of the intervention and the subject of the research carried out at PGRI junior high school 1 Palembang with the consideration that of the seven indicators of student's anxiety in facing the exam, most experienced by PGRI junior high school 1 Palembang students. For this reason, this research was carried out at PGRI junior high school 1 Palembang.

\begin{tabular}{ccc}
\hline Measurement & & Experiment $(\mathbf{N}=\mathbf{1 8})$ \\
\hline Pretest & M & 124 \\
& SD & 3.64387 \\
Posttest & M & 67 \\
& SD & 3.86580 \\
\hline $\mathrm{z}$ & & -2.668 \\
$\mathrm{p}$ & & $.008(<0,05)$ \\
\hline
\end{tabular}

Table 1. Mean, standard deviation and Wilcoxon test result

Furthermore, the effectiveness test of the group counseling service model with relaxation techniques assisted by instrumental music to reduce students' anxiety in facing the exam was analyzed with Wilcoxon Test through the SPSS program. Wilcoxon's test requirement is the difference between two groups of data with normal distribution. The researcher must first test the normality of the differences between the two groups. The researcher tested the normality with Shapiro Wilk and obtained a significant value of 0.005 
( $>0.05)$ meaning that the data is normal. Then the analysis was performed with the Wilcoxon test. The following will be elaborated on the results of the effectiveness testing of the group counseling service model with relaxation techniques assisted by instrumental music to reduce students' anxiety in facing the exam. Wilcoxon test results are described in Table 1. Based on the results of the Wilcoxon Test obtained Asymp.sig. (2-tailed) of 0.008 with the significant $5 \%$ then $0.008<0.05$ so that the null hypothesis is rejected and the alternative hypothesis is accepted, it is concluded that the group counseling model with technique relaxation assisted by instrumental music proved to be effective for reducing the anxiety of students in facing exams.

Group counseling with relaxation techniques assisted by instrumental music can be used in reducing the anxiety of students in facing exams. Conducted in group counseling situations in group dynamics so that students are useful in expressing problems regarding students' anxiety in facing the test together with other students. Through the stages of group counseling, namely: 1) the opening stage, 2) the transition stage, 3) the activity phase, 4) the termination stage. Relaxation techniques assisted by instrumental music will be carried out in the 3rd stage (activity stage) in group counseling. At the activity stage in group counseling, group leaders will provide relaxation techniques assisted by instrumental music to reduce the anxiety of students facing exams as group members. Group members will be given topics discussed at each meeting in each group counseling session. The topics were finally able to reduce indicators in students' anxiety in facing the exam. At the activity stage in group counseling, group leaders will provide relaxation technique strategies assisted by instrumental music to reduce students' anxiety in facing the exam.

Based on the results of the study, it was found that there was a significant difference between the average score scores of students 'anxiety in facing the exam before receiving group counseling services and the average score of students' anxiety in facing the exam after receiving group counseling services. The implementation of group counseling services with relaxation techniques assisted by instrumental music is effective in reducing the anxiety of students facing exams.

Based on the results of data analysis with Wilcoxon Test, the purpose of the group counseling model with relaxation techniques assisted by instrumental music to reduce students 'anxiety in facing the exam has been achieved, namely with the changes from the results of the initial evaluation and the results of the final evaluation on students' anxiety in facing the exam owned by the eighth grade students of PGRI junior high school 1 Palembang.

This research is supported by the results of study that stated music is always associated with a healthy mind which states that music is a sound that we often hear, music can entertain the soul, arouse enthusiasm and clear the mind (Baker \& Bor, 2008; Salim, 2006). Authors need to emphasize that utilized music in this research is slow and soft instrumental. Music makes one able to express themselves freely, and music can make people smarter, reduce memory, reduce creativity, nourish the body, reduce emotional intelligence, etc. Furthermore, this findings are consistent with systematic desensitization techniques and behavioral techniques can reduce exam anxiety in students (Otta \& Ogazie, 2014), biofeedback relaxation training reduce anxiety and improving academic performance (Aritzeta et al., 2017), and the combination of relaxation technique with cognitive behaviour therapy optimizes academic performance (Akinsola \& Nwajei, 2013).

The result of this research important in enriches the literature on treatment anxiety. The relaxation technique within group counseling asked the counselee to associate relaxing situation or comfortable and steady state then visualized it when have to face anxious situations. Thus, the anxiety would disappear by little or disappear at all. Therefore, guidance and counseling teacher or school counselor should consider to implement this method at their workplace to help student with anxiety particularly when facing exam. 
This research limitation was not conduct a long term assessment, so researcher did not know whether the impact of treatment will permanent or temporarily. Therefore, authors suggested for further investigation should conduct continuously assessment after posttest to confirm the long term impact of the treatment.

\section{CONCLUSIONS}

Based on the result of the research, group counseling with relaxation technique assisted with instrumental music significance to reduce students' anxiety when facing exam. The result of this research has enriches the empirical based literature and practical on treatment anxiety. Thus, this method should be considered by mental health service practitioners as their helping technique.

\section{ACKNOWLEDGMENTS}

The authors present their sincere appreciation goes to everyone who has contributed their precious time and thought on improving the contents of this article.

\section{AUTHOR CONTRIBUTIONS STATEMENTS}

The idea of this research was came from AA. The investigation started with analyzing the phenomenon of examination anxiety and theories within this narrow the area. NN was helping AA to collect the data with psychological scale and interview with the guidance and counseling teachers. ZJ kept collecting literatures within the field of the study as AA and NN collecting the data. The report of this study was written by AA, NN and ZJ respectively to check and recheck if there was missing from the investigation.

\section{REFERENCES}

Akinsola, E. F., \& Nwajei, A. D. (2013). Test Anxiety, Depression and Academic Performance: Assessment and Management Using Relaxation and Cognitive $\begin{array}{llll}\text { Restructuring } \quad \text { Techniques. } & \text { Psychology, } 24 .\end{array}$ https://doi.org/10.4236/psych.2013.46A1003

Aldrin, N. (2014). Healing-Talks Keajaiban Kata-kata. Depok: Puspa Swara. Retrieved from Google Scholar

Aritzeta, A., Soroa, G., Balluerka, N., Muela, A., Gorostiaga, A., \& Aliri, J. (2017). Reducing Anxiety and Improving Academic Performance Through a Biofeedback Relaxation Training Program. Applied Psychophysiology and Biofeedback, 42(3), 193-202. https://doi.org/10.1007/s10484-017-9367-z

Baker, F., \& Bor, W. (2008). Can music preference indicate mental health status in young people? Australasian Psychiatry, 16(4), 284-288. https://doi.org/10.1080/10398560701879589

Barlow, D. H. (2013). Anxiety and its disorders: The nature and treatment of anxiety and panic. Guilford Publications. Retrieved from Google Scholar

Corey, G. (2013). Theory and practice of counseling and psychotherapy. Belmont, CA: Cengage Learning. Retrieved from Google Scholar

Gunarsa, D. S. (2008). Psikologi Praktis: Anak, Remaja, dan Keluarga. Jakarta: PT. BPK Gunung Mulia. Retrieved from Google Scholar

Hawari, A. D. (2008). Manajemen Stres, Kecemasan dan Depresi. Jakarta: Fakultas Kedokteran UI. Retrieved from Google Scholar 
Levinson, C. A., \& Rodebaugh, T. L. (2016). Clarifying the prospective relationships between social anxiety and eating disorder symptoms and underlying vulnerabilities. Appetite, 107, 38-46. https://doi.org/10.1016/j.appet.2016.07.024

Maba, A. P. (2017). Paradoxical intervention dalam bimbingan dan konseling untuk mengatasi kecemasan. Counsellia: Jurnal Bimbingan Dan Konseling, 7(2), 99-109. https://doi.org/10.25273/counsellia.v7i2.1852

Otta, F. E., \& Ogazie, C. A. (2014). Effects of systematic Desensitization and study behaviour techniques on the Reduction of test phobia among in-School Adolescents in Abia state. World Journal of Educational Research, 1(3), 7. Retrieved from http://wjer.org/WJER_Vol.\%201,\%20No.\%203,\%20August\%202014/EFFECTS\%200 F\%20SYSTEMATIC.pdf

Prayitno. (2005). Layanan Bimbingan dan Konseling Kelompok. Jakarta: Ghalia Indonesia. Retrieved from Google Scholar

Reilly, T., \& Edwards, B. (2007). Altered sleep-wake cycles and physical performance in

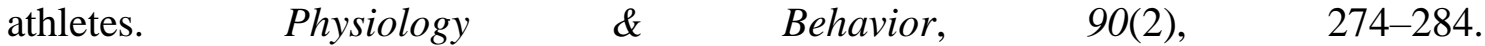
https://doi.org/10.1016/j.physbeh.2006.09.017

Salim, D. (2006). Terapi Musik Teori dan Aplikasi. Yogyakarta: Galang Press. Retrieved from Google Scholar

Sugiyono, M. P. P. (2007). Pendekatan Kuantitatif. Kualitatif, Dan R\&D, Bandung: Alfabeta. Retrieved from Google Scholar

Wibowo, M. E. (2005). Konseling Kelompok Perkembangan. Semarang: UNNES Pers. Retrieved from Google Scholar

Willis, S. S. (2004). Konseling Individual Teori dan Praktek. Bandung: Alfabeta. Retrieved from Google Scholar 